Accepted refereed manuscript of:

Stephan H (2017) The Discursive Politics of Unconventional Gas in Scotland: Drifting Towards Precaution?, Energy Research and Social Science, 23, pp. 159-168.

DOI: $\underline{10.1016 / \text { j.erss.2016.09.006 }}$

(C) 2016, Elsevier. Licensed under the Creative Commons AttributionNonCommercial-NoDerivatives 4.0 International http://creativecommons.org/licenses/by-nc-nd/4.0/ 


\title{
The Discursive Politics of Unconventional Gas in Scotland: Drifting Towards Precaution?
}

\author{
*** Accepted on 20 September 2016 for publication in Energy Research \& Social Science ***
}

\author{
*** Available online 27 October 2016 ***
}

\author{
Dr Hannes R. Stephan \\ Division of History \& Politics \\ University of Stirling \\ Stirling, FK9 4LA, Scotland, U.K. \\ Email: h.r.stephan@stir.ac.uk
}

\begin{abstract}
:
With a long history of oil and gas production and potentially significant reserves of unconventional gas, Scotland represents a notable case amid the growing international controversy over unconventional gas development (UGD). This article applies argumentative discourse analysis to the Scottish debate over UGD and identifies several important storylines which have mobilised different discourse coalitions and shaped public opinion as well as policy-making. For now, anti-UGD storylines appear more encompassing and have achieved greater resonance. Of particular interest, however, is the role of the Scottish government as a third discourse coalition. Through a moratorium on all forms of UGD and a cautious 'evidence-based approach', the government has established a form of discursive dominance and has successfully minimised electoral risks. But its anti-Westminster storyline - created in the run-up to the Scottish independence referendum in 2014 - has undermined the government's pragmatic strategy by invoking Scottish resistance to the UK's pursuit of shale gas. While the evidence-based approach persists as the preeminent storyline, its interpretation has 'drifted' from (1) a modestly reformed planning policy to (2) an exercise in scientific fact-finding combined with a public consultation and, arguably, (3) to a precautionary approach that might lay the foundation for an extended moratorium.
\end{abstract}

Keywords: Unconventional gas; fracking; discourse coalitions; Scotland

\section{Introduction}

Ever since US shale gas production accelerated in the mid-2000s, unconventional gas development (UGD) has grown into a major political controversy in many countries. The US has witnessed increasing mobilisation against hydraulic fracturing (or 'fracking') of shale gas wells. In Europe, a number of countries have imposed indefinite or temporary moratoria on shale gas: Belgium, Bulgaria, Czech Republic, France, Germany, Ireland, and the Netherlands.

In the UK, former Prime Minister Cameron announced in January 2014 that the country was going "all out for shale" (Guardian, 13 January 2014). Anti-UGD mobilisation across the country has not weakened the UK government's resolve, but it has led to moratoria by the devolved regional governments in Scotland and Wales. In Scotland, the first application to drill for coalbed methane was made in 2011. A 2014 report by the British Geological Survey found potentially lucrative reserves 
of unconventional gas throughout Scotland's 'central belt' region [50]. But the Scottish government (constituted by the Scottish National Party (SNP)) imposed a moratorium on shale gas and coalbed methane (CBM) in January 2015, and on underground coal gasification (UCG) in October 2015, by suspending all relevant planning applications. The government has ordered several impact assessments on public health, transport, the economy, and climate change as well as further scientific studies on decommissioning, seismic activity, and monitoring. A public consultation during winter 2016/17 will follow and a decision on shale gas and CBM may be due by summer $2017 .{ }^{1}$

Scotland represents an interesting test case for UGD. The country is marked by a long history of oil and gas production, but many offshore fields are now depleted and profitability is falling. Two very different visions of Scotland's energy future are being propagated. The pro-UGD camp hails the new unconventional onshore reserves as partly compensating for the rapid decline of offshore production. It calls for a realistic energy policy and a more gradual low-carbon transition [23], citing scientific reports that highlight potential opportunities and judge the risk to public health and environment as relatively low $[67,57]$. The anti-UGD camp deploys a zero-sum narrative in favour of a country powered by 100 percent renewable energy [75] and promotes a phase-out of fossil fuels and the gradual winding down of a fossil fuel-based petrochemical industry [49].

While there are similarities with UGD-related discourse and regulatory dynamics in other contexts particularly with England, the Netherlands, and New York State - the Scottish case also has distinctive characteristics. The central belt region has witnessed simultaneous controversies over all three forms of unconventional gas. Furthermore, the debate has been decisively shaped by the government's insistence on an evidence-based approach and by the Scottish independence referendum (September 2014), giving rise to partially distinct political and discursive dynamics.

This article employs a discursive approach - based on Hajer's argumentative discourse analysis [34] to examine the debate over UGD in Scotland. Hajer ([35]: 67) defines discourse as "an ensemble of ideas, concepts, and categories through which meaning is given to social and physical phenomena, and which is produced and reproduced through an identifiable set of practices." While material resources and political networks markedly shape political outcomes, the power of actors is also "at least in part discursive" ([52]: 169). Rhetorical skills and persuasive storylines significantly influence both the wider public and policy-makers.

Industry and other pro-UGD actors deploy a variety of storylines, while opponents work to undermine these with their own narrative schemes. "Linkages with prevailing societal discourses" (ibid.), often described as 'resonance', can translate into considerable discursive power. For instance, such is the narrative force of the 'renewables revolution' that the pro-UGD camp is working hard to dispel the image of UGD as "a throwback to the bad old days" of heavy industry [23].

Discourse and argumentation are central because political actors cannot stand aside from discursive battles. Actors' understanding of the policy problem itself, as well as its solutions, has been discursively constructed over many years. Their interests are, at least to some extent, "incomplete, ambiguous, and shaped by contingent discourses in which they are embedded" ([68]: 1882). Which storylines resonate and can decisively empower pro- or anti-UGD coalitions is a matter of contextual, empirical analysis.

This article thus pursues two main objectives. First, it analyses the narratives (or 'storylines') of three different actor coalitions in significant detail and contributes to a comprehensive understanding of the Scottish debate on UGD. Second, it elucidates the evolution of the debate - particularly the 'discursive drift' of the Scottish government's narrative from hesitation to discursive dominance (the 'evidence-based approach') and, more recently, to precautionary scepticism. Although the

\footnotetext{
${ }^{1}$ The moratorium on UCG followed a separate timetable and was made permanent on 6 October 2016.
} 
government's cautious and evidence-based approach continues to exert discursive dominance, this will likely be a temporary state of affairs.

\section{Context and Methods}

The current regulatory framework for UGD in the UK relies on multiple levels of governance and different regulatory authorities [11]. Companies have to purchase a time-limited exploration and development license for a particular area from the UK government. Before they can start to drill test wells, authorisation is required from the UK government's Department for Business, Energy, and Industrial Strategy, the Health and Safety Executive, and the Coal Authority (for CBM and UCG). Further necessary permissions have been devolved to the Scottish level and must be obtained from the local authority and the Scottish Environmental Protection Agency. The Scottish government issued a revised planning policy in June 2014 to stipulate public consultation, risk assessments, and appropriate buffer zones for shale gas and CBM. Moreover, the UK will soon devolve both licensing and mineral access rights for onshore oil and gas extraction to Scotland [62]. The issue of access rights had become controversial after the UK government's decision to change trespass rules and allow drilling at $300 \mathrm{~m}$ or more under privately owned land.

As one of the first studies to examine the Scottish debate over unconventional natural gas development, this article draws on insights from existing discursive analyses of energy controversies $[9,53,60]$. Given the dearth of secondary material on Scottish UGD, extensive media and documentary analysis as well as semi-structured interviews represent the main empirical sources. Numerous reports by and statements given to UK broadsheets (Guardian, The Times), news websites (BBC News, Scottish Energy News), and Scottish newspapers (Courier, Daily Record, Falkirk Herald, Herald, The National, Scotsman, Sunday Herald) between August 2013 and June 2016 ( $n=282$ ) were analysed - with the help of the LexisNexis database and newspaper online archives, using the search strings "shale gas", "fracking", and "coal gasification". Key government documents, records of parliamentary debates, and leaflets and pamphlets by pro- and anti-UGD actors were also examined.

Through initial selective sampling as well as snowball sampling, nine semi-structured interviews with key actors were conducted (Table 1 ) to corroborate positions and narratives established by media and documentary analysis and to gain deeper insights into political and discursive dynamics. In the context of fast-moving political events, statements made in interviews were sometimes guarded and indicated possible future revision. Permission was obtained for seven of the interviews to be recorded and transcribed.

TABLE 1: Semi-structured interviews with anonymised respondents

\begin{tabular}{|l|l|l|}
\hline Date & Placeholder & Organisation \\
\hline $13 / 04 / 2015$ & Interview A & Public health expert (academia) \\
\hline $19 / 05 / 2015$ & Interview B & INEOS Upstream \\
\hline $20 / 05 / 2015$ & Interview C & UNISON Scotland (trade union) \\
\hline $27 / 05 / 2015$ & Interview D & Scottish Trades Union Congress (STUC) \\
\hline $01 / 06 / 2015$ & Interview E & Senior partner, global law firm \\
\hline $04 / 06 / 2015$ & Interview F & Scottish Environment Link (NGO umbrella group) \\
\hline $12 / 06 / 2015$ & Interview G & National Farmers Union Scotland (NFUS) \\
\hline $11 / 08 / 2016$ & Interview H & Anti-UGD activist, Frack Off Scotland \\
\hline $28 / 08 / 2016$ & Interview I & Anti-UGD activist, Edinburgh \\
\hline
\end{tabular}


The research data was imported into QSR Nvivo software and analysed through a combination of deductive and inductive approaches. Emphasis was placed on the 'template style' based on a preliminary list of codes which were derived from the broader literature [48], namely themes or frames uncovered by previous research. However, to counteract the risk of merely confirming the results of existing studies on shale gas, inductive openness was maintained and new themes were pursued in a second round of coding. Overall, a reflexive and iterative research design ([8]: 26) allowed for the identification of relevant patterns, storylines and associated actors (Table 2).

My discourse-analytical approach is informed by the emerging literature on UGD in the UK and other countries. Cotton et al. [17] provide a pioneering discursive analysis of the UK debate over shale gas and Metze [46] examines "framing contests" in the Dutch debate. Cotton [15] uses Q-methodology to identify specific areas of agreement and contestation. Bomberg [7] undertakes a systematic content analysis of UK media frames, assesses their potential effectiveness (or resonance), and detects a "growing dominance of more parochial frames" over broader national or global discourses regarding the economy or climate change. Hilson [39] evaluates the limited legal relevance of such global frames in England's planning and regulatory procedures. Williams et al. [74] scrutinise discourses of risk, while Jaspal and Nerlich [43] and Upham et al. [72] adopt a social representations perspective to explore how hydraulic fracturing is constructed by the media and how it is perceived by citizens.

Ashmoore et al. [1] apply a similar method to examine newspaper coverage in three US states, whereas Blair et al. [6] focus on media coverage in Colorado and highlight the importance of uncertainty for framing shale gas. Dodge and Lee [19] explain policy gridlock on fracking in New York State through the absence of a "shared discursive space". Comparative research is also beginning to emerge. Metze and Dodge [47] examine policy dynamics in New York State and the Netherlands, while Goldthau and Sovacool [33] analyse interpretive frames in Bulgaria, Poland, and Romania.

Finally, a growing number of writings address UK policy-making. Cairney et al. [11] offer a comprehensive account of UK policy dynamics and interest group formation. They apply the advocacy coalition framework to show how actor coalitions exchange information in order to reduce both political and scientific uncertainty. Hays et al. [38] scrutinise the quality and extent of scientific knowledge about hydraulic fracturing technology, while Hawkins [37] evaluates the robustness of England's regulatory system for fracking.

Although there is some overlap of discursive methods with policy and institutionalist analyses, Hajer's argumentative discourse analysis (ADA) places an even stronger emphasis on the vague and flexible nature of coalitions as well as on discursive strategies of problem definition and persuasion $[34,26]$. Such divergent interpretations are not surprising because the political salience of UGD is high and the role of scientific expertise is complex. Given that ample "counter expertise" ([26]: 109) is often available, scientific knowledge rarely settles political contests in the short term [60]. This 'politicised' appraisal of scientific expertise contrasts with the Scottish government's ambition for a resolutely 'evidence-based' approach to UGD. Ultimately, the UGD controversy is a debate about moral and political choices which are linked to different interpretations of available scientific knowledge $[11,21,16,22]$.

\section{A Discourse-Analytical Approach}

Scientific complexity is the starting point for argumentative discourse analysis (ADA). Environmental and energy politics are deeply affected by "discursive manipulation" whereby political actors seek to play down "measurable indicators", reduce complexity, and set the political agenda by drawing attention to "simplified answers" ([18]: 26). In the Scottish debate, relevant examples include a 'balanced energy policy' or an 'evidence-based approach'. The latter term is routinely used by the 
Scottish government and has particular resonance due to the elevated status of scientific knowledge in the modern age [73]. The anti- and the pro-UGD coalitions also lay claim to evidence-based advocacy, but interpret available scientific studies in different ways. The Scottish government's insistence on an evidence-based approach seeks to bolster its reputation for competent governance, while also preserving significant leeway for its eventual decision on UGD. ${ }^{2}$ Ultimately, however, the political case has to be made alongside the scientific case. This explains the planned public consultation and the public engagement processes that were conducted by major companies (INEOS and Cluff Natural Resources (CNR)).

\section{Discursive Hegemony}

ADA conceptualises politics "as a struggle for discursive hegemony in which actors try to secure support for their definition of reality" ([34]: 59). Achieving discursive hegemony serves to close down the debate and establish UGD as a widely accepted technology. However, in the Scottish context, given the strength of opposing discourse coalitions, it appears more likely that multiple discourses will continue to co-exist [20], leading to either cautious progress on UGD or an indefinite (but reversible) moratorium.

If politics is understood as a discursive struggle, it genuinely matters who is able to set the terms of the debate, which issues are emphasised, and which ones are deemphasised or excluded. Once actors are compelled to use the "ideas, concepts, and categories of a given discourse", Hajer ([34]: 60) speaks of 'discourse structuration'. The discursive dominance of the 'evidence-based' approach manifests this condition. To radically depart from it and establish a new problem definition carries the risk of being perceived as illegitimate or unintelligible. Structuration by itself, however, does not guarantee that policy will be shaped by the dominant storyline. The ultimate objective is therefore to achieve "discourse institutionalisation" whereby a discourse "solidifies into institutions and organizational practices" ([36]: 64). Only once structuration and institutionalisation have both been achieved one can speak of discursive hegemony ([34]: 61).

Scotland's current moratorium on UGD can be regarded as a precarious and temporary institutionalisation ${ }^{3}$ of the cautious, 'evidence-based' approach which is routinely proclaimed by the Scottish government. The moratorium is publicly endorsed by both pro- and anti-UGD camps, but neither regards it as their preferred outcome. This and a likely decision in 2017 mean that this partial form of discourse institutionalisation will not last. While the pro-UGD coalition seeks more expansive opportunities for test drilling (which is, to a limited extent, allowed under the moratorium) and nearterm UGD on a commercial scale (Interviews B, E), the anti-UGD coalition campaigns for a permanent ban or at least a highly restrictive regulatory framework (Interview F). Overall, therefore, discursive hegemony does not currently apply. Yet, the government's discourse and policy are influential and command sufficient support to exert a form of discursive dominance.

\section{Discursive Power or Resonance}

Hajer ([34]: 59) suggests that three factors are particularly important to assess discursive power. First, credibility requires that discursive positions are internally consistent and communicated in a persuasive manner. The pro-UGD coalition thus emphasises that UK/Scottish operations will be models of best practice, while acknowledging that UGD in the US and Australia has been insufficiently regulated. Second, acceptability implies that discursive positions are acknowledged as

\footnotetext{
${ }^{2}$ A similar approach prevailed in New York State for six years until hydraulic fracturing was banned in December 2014 ([66]).

${ }^{3}$ See Bulkeley [9] for a similar example of partial discourse institutionalisation.
} 
"attractive or necessary" [ibid.]. Here, the issues of financial benefits for local communities as well as narratives of energy security and economic development come into play. Third, trust assumes that actors are believed to be truthful - especially regarding potential risks, uncertainties, remedial capacity, and motives - and that their past behaviour or procedures provide sufficient evidence. The industry cites a programme of local community meetings and exhibitions to demonstrate participatory and respectful decision-making (Interview B), but companies such as INEOS have experienced turbulent industrial relations in the recent past (Interviews C, D).

Discursive interventions seek to achieve "rhetorical or symbolic resonance with social and cultural values and norms, or rekindle older traditions and sentiments" ([18]: 22). Although, over the long term, cultural identities, values, and norms are constructed and sustained by discursive practices, they are difficult to deconstruct or reinterpret in the short term. The concept of resonance captures the ideational fit between such sedimented identities and values, on the one hand, and novel discursive interventions on the other. Benford and Snow ([4]: 621) suggest that resonance hinges on experiential commensurability and narrative fidelity. Experiential commensurability gauges to what extent discursive frames resonate with the lived, everyday experience of the target audience. When anti-UGD groups speak of a "toxic nightmare" and paint an image of a "dirty" industry responsible for hazardous pollution [25], the public's cognitive resources include oil- and gas-related accidents in Scotland (relatively few and mostly offshore) and global, heavily mediatised examples of fossil fuels production, ranging from tar sands in Canada to shale gas incidents and oil spills in the US, and coalbed methane in Australia. Adverse events with a clear connection to UGD, even if occurring in distant places, can be used to boost negative experiential commensurability.

Narrative fidelity (used interchangeably with cultural resonance) captures the significance of cultural traditions and values. UGD can be seen as a logical and beneficial continuation of the Scottish tradition of oil and gas production, reaching all the way back to the mid-nineteenth century. Thus, pro-UGD actors intermittently attempt to stoke pride in Scottish industrial history, while recasting UGD as a bridge to a greener future. Identity-based appeals are woven into arguments about economic benefits and energy security, with INEOS [40] declaring that, thanks to UGD, Scotland "could play to its strength, securing its position as an energy exporter." The search for cultural resonance with Scotland's long history of fossil fuel extraction is palpable here. But history can equally be represented as catalogue of health and safety disasters linking the Scottish mining industry to contemporary petrochemicals ([45], Interview H). In addition, anti-UGD actors portray the technology as a diversion from Scotland's destiny as a pioneer in the global low-carbon energy transition, weakening its commitment to ambitious climate and energy targets ${ }^{4}$ and undermining its future as an exporter of cleaner, low-carbon technologies.

\section{Storylines and Discourse Coalitions}

The above dimensions are central to both anti- and pro-UGD storylines. Storylines are mechanisms for "the clustering of knowledge, the positioning of actors, and [... for] the creation of coalitions" ([34]: 63). At their best, storylines offer a "short, condensed, and often metaphorical expression" ([68]: 1884) of policy problems and appropriate solutions. An example from UK energy policy is the oft-used phrase of 'keeping the lights on' which is employed to stress energy security and call into question a speedy low-carbon energy transition. It exudes pragmatism, appeals to 'common sense', and creates an opportunity for discursive closure [34], that is, a stabilisation of the problem definition.

\footnotetext{
${ }^{4}$ The 2009 Scottish Climate Change Act commits the government to a 42 percent reduction of GHG emissions by 2020 and of 80 percent by 2050 (compared to 1990). A separate target aims at providing 100 percent of electricity from renewable sources by 2020.
} 
Although often resilient [26], storylines are potentially vulnerable to contestation (Palmer 2010) - be it through new empirical evidence, exogenous shocks, or cultural symbols and countervailing narratives. The scope and complexity of storylines varies across the literature. In this article, I take storylines to represent the discursive frames that support overarching pro- and anti-UGD narratives. Storylines serve as the "discursive cement" of discourse coalitions ([34]: 65). These coalitions are constituted by actors who consider that their own beliefs and interests are served by one or more associated storylines. Importantly, neither beliefs nor interests need to be shared by discourse coalitions [9]. Actors sometimes drift in and out of discourse coalitions over time, as illustrated by the trade union GMB Scotland [32] which initially subscribed to the Scottish Trade Union Council's critical stance, but later declared its support for UGD. Storylines can also overlap - for instance, economic development and energy security are addressed by both pro- and anti-UGD coalitions (see Table 2). This may create the foundations for potential compromise and convergence [47], but in Scotland the fundamental opposition between two grand narratives - natural gas as a 'bridge' fuel and the renewables 'revolution' - has so far prevented this.

TABLE 2: Key storylines and resonant values, goals, and interests

\begin{tabular}{|c|c|c|}
\hline Pro-UGD & Anti-UGD & Reserved \\
\hline \multicolumn{3}{|c|}{$\begin{array}{c}\text { Economic development } \\
\text { (resonates with: secure livelihoods, well-being, wealth) }\end{array}$} \\
\hline \multicolumn{3}{|c|}{$\begin{array}{c}\text { Energy security } \\
\text { (resonates with: independence, reliability, affordability) }\end{array}$} \\
\hline $\begin{array}{c}\text { Reassurance } \\
\text { (resonates with: scientific authority, socio- } \\
\text { political trust) }\end{array}$ & $\begin{array}{l}\text { Uncertainty and potential risks } \\
\text { (resonates with: precaution, mistrust) }\end{array}$ & $\begin{array}{l}\text { Evidence-based approach } \\
\text { (resonates with: scientific } \\
\text { authority, regulatory } \\
\text { competence, 'common sense', } \\
\text { trust) }\end{array}$ \\
\hline \multirow[t]{2}{*}{$\begin{array}{l}\text { Social and environmental } \\
\text { responsibility } \\
\text { (resonates with: global ethics, pragmatism) }\end{array}$} & $\begin{array}{c}\text { 'Bad governance' and } \\
\text { energy justice } \\
\text { (resonates with: mistrust, inequality, } \\
\text { exclusion) }\end{array}$ & $\begin{array}{l}\text { Anti-Westminster } \\
\text { (resonates with: independence, } \\
\text { nationalism, responsibility) }\end{array}$ \\
\hline & $\begin{array}{c}\text { Threat to low-carbon energy } \\
\text { transition } \\
\text { (resonates with: optimism, } \\
\text { technological transformation) }\end{array}$ & \\
\hline
\end{tabular}

\section{Membership of Discourse Coalitions}

The UGD debate in Scotland plays out as a contest between three discourse coalitions. The pro-UGD discourse coalition assembles major industrial players with economic interests in shale gas and coalbed methane (INEOS, IGas) and underground coal gasification (Cluff Natural Resources, Five Quarter Energy), the industry association UK Onshore Oil \& Gas (UKOOG), one large trade union (GMB Scotland), the Scientific Alliance (an NGO), the Scottish Conservative Party, and a number of academic experts. The anti-UGD discourse coalition includes around 28 local activist organisations (Broad Alliance against Unconventional Gas), several Scottish environmental NGOs (Friends of the Earth Scotland, WWF Scotland, RSPB Scotland, Scottish Wildlife Trust, Scottish Environment Link), some trade unions (UNISON Scotland, Scottish Trade Union Council (STUC)), a few academic experts, the Scottish Green Party, the Scottish Labour Party ${ }^{5}$, and 'SNP Members Against Unconventional Gas' (SMAUG) - an influential section of the governing Scottish National Party (SNP).

\footnotetext{
${ }^{5}$ Scottish Labour initially pledged a cautious approach to UGD (incl. binding local referendums), but called for a complete ban in the run-up to the Scottish parliamentary elections of May 2016.
} 
The third coalition is less congruent and temporary. It mainly consists of the Scottish government (plus significant sections of the SNP). In addition, there are numerous organisations which have not yet formulated a clear position, but take an interest in UGD and are broadly supportive of a cautious, inclusive approach. These comprise, among others, the National Farmers Union Scotland (Interview $\mathrm{G})$ and the Church of Scotland [12].

\section{Pro-UGD Storylines}

Pro-UGD discourse is focused on instilling a sense of opportunity, on demonstrating tangible benefits of unconventional gas, and on downplaying potential risks associated with extraction. The evidencebased approach of the Scottish government is interpreted as a reliance on sound scientific knowledge. UGD technologies are seen as proven, while potential risks are described as contextual and site-specific in terms of regulatory frameworks and geology (Interview B).

\section{(1) Economic development and risks}

At the broadest level, UGD is inscribed into the project of rebalancing the economy and boosting manufacturing. When used as feedstock, shale gas is needed to manufacture many desirable, "highvalue' consumer products, construction materials, and even innovative materials for wind turbines and solar panels (INEOS 2015a). Special emphasis is placed on the accelerated decline of Scotland's North Sea oil and gas production and the closure of most remaining coalmines. UGD is praised for compensating for the loss of well-paid jobs and tax revenues $[13,40]$.

For the Grangemouth area alone, INEOS expects that around 6,000-7,000 new jobs could emerge in shale gas extraction and the wider supply chain. INEOS has also promised tangible economic benefits to affected communities. The company will share 4 percent of shale gas revenues with landowners and a further 2 percent with the wider community. Over time, this may generate significant economic benefits for local communities, with headlines figures quoted as $£ 375 \mathrm{~m}$ for a $10 \mathrm{~m}^{2} \times 10 \mathrm{~m}^{2}$ development area and $£ 2.5 \mathrm{bn}$ for the entire project [42]. And if Scotland became a pioneer in UCG technology, a CNR-commissioned report projects significant benefits of around $£ 66 \mathrm{bn}$ for the Scottish economy and nearly 5,000 jobs in extractive and chemicals sectors [5].

Narratives of opportunity are often accompanied by warnings about the risks of rejecting UGD or moving too slowly, especially in comparison to major competitors in the UGD business, such as the US and China $[71,40]$. Initially, INEOS reacted to the prospect of moratorium by warning that its gas cracker at Grangemouth would not have a long-term future unless an "indigenous source" could be developed (Scotsman, 10 February 2015). After reportedly receiving assurances from the government (National, 16 July 2015), the company declared its support for a temporary moratorium (National, 29 April 2015). It now maintains that UGD "can help to protect manufacturing and jobs by securing competitive [...] raw materials" [42].

Slow decision-making has clearly affected the fortunes of UCG technology. The industry needs sufficient investment certainty to finance exploration and extraction. As CNR [14] warned, "[e]ven a temporary delay until 2016, and the uncertainties this would cause, would set us back considerably (maybe fatally) for the future." In response to the moratorium on UCG (in October 2015), CNR put on hold its Scottish project and shifted its investment elsewhere. Five Quarter Energy even collapsed in March 2016.

\section{(2) Energy security}

In its broadest form, energy security is concerned with "how to equitably provide available, affordable, reliable, efficient, environmentally benign, properly governed and socially acceptable 
energy services" ([64]: 5344). In the UGD debate, however, it is usually more narrowly linked to security of gas supplies and affordable energy prices. The Scottish Conservatives insist that "increasing the domestic supply of gas is bound to have a beneficial impact on energy prices" ([58]: 30632). However, most pro-UGD actors now play down this argument because the integrated nature of European and global markets for natural gas will likely act as a price equaliser.

With regard to security of supply, much is made of the projection that the UK's dependence on imports of natural gas (from often politically unstable countries) will likely rise to more than two thirds of domestic consumption by 2020. INEOS [40] predicts serious consequences for the domestic gas market if Europe continues to rely on Russian gas: "the UK will be exposed to shortages and price volatility over the next few decades." While acknowledging uncertainty about scale and commercial feasibility, INEOS [40] estimates that a mere 10 percent of the UK's total reserves would provide enough gas for over four decades. And CNR forecasts that inaccessible coal reserves harnessed by UCG could produce "enough gas to fuel Britain cheaply and efficiently for hundreds of years" (Courier, 22 August 2013).

\section{(3) Reassurance}

The need for reassurance has become increasingly evident in the face of determined opposition to UGD [7]. The storyline emphasises the value of public consultation to obtain the necessary 'social licence' for UGD (e.g. [40]). For INEOS, consultation proceeds through a series of public exhibitions and community meetings, while online information leaflets and video clips engage in public relations and science communication (Interview B).

A core discursive strand plays down the novelty of unconventional gas technologies [39]. UKOOG [70] draws attention to the UK's first instances of fracking in the 1960s and estimates that 10 percent of the country's 2,000 onshore wells have been hydraulically fractured. CNR (2015a) points to a domestic UCG project in the 1950s and substantial government-funded research since the late 1990s. A second step is to emphasise the specificity of Scottish geology and the UK's robust regulatory framework. INEOS [41] points to "rare instances" of pollution events in the US caused by "poor practice and inadequate regulation" and insists that these issues would be "straightforward to avoid in the UK." The company's information leaflets methodically summarise some of the scientific literature and highlight broadly supportive reports written by authoritative organisations (e.g. [67]). CNR maintains that there are "no inherent risks" associated with UCG and that any comparison to major problems observed in Australia can be discounted due to geological reasons (eight times deeper coal seams in Scotland) and greater regulatory stringency (CNR 2015a; Courier, 25 March 2015; The National, 17 August 2015).

To boost the storyline's credibility, industry actors recognise that UGD is not a completely risk-free enterprise. INEOS [41] maintains that "the risks are manageable and comparable to other practices". CNR speaks of "negligible risk" and proposes to "proceed in a cautious manner with a small pilot operation with rigorous oversight" (Falkirk Herald, 2 March 2015). Thus, the discourse of reassurance is combined with a science-based, gradual method that fits well with the Scottish government's evidence-based approach.

\section{(4) Social and environmental responsibility}

This storyline emphasises that UGD is not merely beneficial for companies, workers, and local communities, but also represents an ethically sound endeavour. Moreover, it responds to the powerful counter-narrative of a renewables-driven energy transition.

First, natural gas is rehabilitated as a cleaner fossil fuel and as a 'bridge' to a low-carbon world. INEOS [40] argues that it will "take a couple of decades [...] to fully transform how the UK generates 
electricity and heat." The Scottish Conservatives point to the US where greater reliance on natural gas has enabled marked reductions in carbon emissions ([58]: 30632) and INEOS [40] invokes an "environmental duty to use gas rather than coal." CNR hails offshore 'clean coal' UCG projects and claims that they would deliver substantial climate mitigation benefits through carbon capture and storage (CCS) technology [55]. Such projects could also "help pay for renewable technologies through their infancy" [54].

Second, the storyline invokes an ethical responsibility for society's energy choices. As the trade union GMB Scotland [32] argues, "[t]he issue for Scotland isn't [...] whether we will use gas or not. [...] The real issue is where we will get our gas from, and who should take the moral responsibility for extracting and supplying the gas we use." This assessment highlights the social and environmental advantages of extracting unconventional gas in a regulatory context with stringent rules, regular monitoring, adequate salaries, extensive workers' rights, and benefits for local communities.

Third, the anti-UGD vision of a speedy transition to an entirely renewables-powered energy system is called into question. INEOS [40] warns that, by 2020, renewables will only account for 31 percent of UK electricity and natural gas still for 29 percent; that 100 percent renewable electricity would require a total of 200,000 wind turbines; that the intermittency of renewables would lead to "power cuts, blackouts and shortages"; and that electric heating would cost three times as much as gaspowered central heating.

Anti-UGD groups are rarely addressed directly, but the Scientific Alliance Scotland accuses them of a 'knowledge deficit' and of harbouring irrational fears (Scotsman, 2 March 2015). A second line of attack questions the legitimacy of activists. CNR's Andrew Nunn describes local opponents as "increasingly extreme groups [who] oppose practically all forms of energy development in Scotland and do not represent the vast majority of the population" [3].

\section{Anti-UGD Storylines}

Similarly vigorous criticisms are voiced by the anti-UGD discourse coalition. These actors interpret the Scottish government's 'evidence-based' approach as an appeal to the precautionary principle (Interviews A, F) whereby potentially risky activities should be prevented "until society can be certain that harm will not arise from the process or [...] is outweighed by the benefits" ([22]: 578). The overall narrative is best summarised by Friends of the Earth Scotland's (FOES 2015d) indictment of unconventional gas as "unsafe, unnecessary, unwanted."

\section{(1) Uncertainty and potential risks}

Descriptions of potential risks to public health and the environment are underpinned by excerpts from scientific studies and by evocative metaphors. A leaflet by the local group 'Falkirk Against Unconventional Gas' (FAUG 2015) refers to the prospect of a "toxic nightmare" caused by substances contained in rock formations, in shale gas itself, and in fracking fluids - such as radioactive matter, radon gas, heavy metals, and airborne chemicals. Examples of incidents from the US and Australia are highlighted to demonstrate the existence of serious hazards (The National, 17 August 2015), and the UK's own experience with UGD is portrayed as a "catalogue of problems" (FOES 2015c). UCG technology is described as "largely untested" and "experimental" (Courier, 14 February 2015; Falkirk Herald, 2 March 2015).

Although concerns over the degradation of landscapes and amenities are sometimes voiced, antiUGD groups seek to insulate themselves from the charge of not-in-my-backyard (NIMBY), largely selfinterested opposition by articulating several other storylines. They also point to opinion polls showing that a majority of Scottish citizens oppose UGD $[76,65,77]$. 
(2) 'Bad governance' and energy justice

Place-based opposition - for instance against CBM and shale gas (around Falkirk) or against UCG (in Fife and Edinburgh) - is a key feature of anti-UGD mobilisation. Bomberg ([7]: 11) speaks of growing concerns across the UK over 'bad governance' and a planning process beset by a "lack of transparency, democracy, and citizen input." Scottish activists criticise the planning system for not acting as a "fair arbitrator", for not giving sufficient space to major objections (climate change, public health), and for allowing developers to operate below the radar by pressing ahead with exploratory drilling [78]. The moratorium is considered to be incomplete because it allows for baseline monitoring and test drilling.

Anti-UGD mobilisation can partly be understood as a demand for 'energy justice' [44], particularly for stronger procedural safeguards [17] that give local councils and citizens more influence. Thus, there are often ethical objections to centralised decision-making and the dominance of narrowly conceived scientific and economic considerations ([16,22], Interview I). Several community councils around Falkirk drafted a comprehensive 'Community Charter' to transform "the narrative of 'fighting against' into 'fighting for'" [79]. The charter invokes the protection of 'cultural heritage', commits the signatories to "truly Sustainable Development", and lists a broad range of environmental, socioeconomic, and cultural goals [24]. This represents a dual riposte to (1) critiques of 'NIMBY' preoccupation with traffic congestion, local amenities, and property prices; and (2) the legal and administrative strictures of the planning system. It also taps into the ongoing debate over land reform, democratic governance, and community ownership in Scotland [78].

\section{(3) Threat to low-carbon energy transition}

A key storyline depicts UGD as undermining Scotland's climate change targets and the renewable energy transition. UGD generates additional fugitive emissions of methane that may cancel out some of its climate change related advantages over coal [30]. Highlighting reports by the UK Parliamentary Committee on Climate Change, opponents underline the limited duration of a natural gas 'bridge' to a fully decarbonised energy system. Assuming that environmental and health impact assessments will have to be carried out for many years to come, FOES [29] concludes that unconventional gas will by that point have missed its brief window of opportunity as a lower-carbon fossil fuel. The planned "dash for unconventional gas" is billed as a "serious distraction from badly needed investment in clean renewable energy" [31].

The thrust of this storyline is to portray unconventional fossil fuels as both wrong-headed and unnecessary. Regarding a potential coal gasification power plant (with CCS) at Grangemouth, Richard Dixon of FOES argues that "[a] carbon capture facility is perhaps useful in somewhere like China [...], but here in Scotland, where renewables are the single biggest source of energy and increasing all the time, we really don't need one" (Times, 28 March 2015). The pro-renewables narrative is firmly in place and it is backed up by opinion polls showing considerable support for renewable energy (e.g. [77]). However, the anti-UGD discourse coalition still has to respond to influential pro-UGD storylines about energy security and economic development.

\section{(4) Energy security}

Taking Scotland's ambitious climate and energy targets for granted allows the critics to question UGD as a major contribution to energy security. According to FOES [30], it may take a decade for significant onshore gas production to come on stream, and recovery rates could be lower than anticipated. Today's investments may even become 'stranded assets' by the late 2040s, once very stringent climate targets loom on the horizon [56]. 
FOES [30] conclude that "the real solution for energy security and a sustainable economy is renewable power and energy efficiency." Given Scotland's potential for renewable energy, there is much stronger emphasis on the former. In the wider UK context, however, Friends of the Earth have also made a case for energy efficiency, demand reduction, and diversification of natural gas imports as an alternative strategy for ensuring energy security [27].

\section{(5) Economic development}

Finally, the prospect of significant economic benefits through UGD is called into question by antiUGD actors. FOES juxtapose relatively short-term job opportunities with long-term risks from drilling. The group argues that there would be relatively few 'itinerant' workers at each drilling site and that jobs may be lost in other sectors, such as tourism and the food and drink industry [28]. The aggregate economic benefits promised by INEOS are questioned on technical grounds (assuming high production rates per well or many wells per square mile) and on moral grounds because some compensation to landowners would already be legally required [28].

By contrast, substantial job creation is claimed as one major benefit of the alternative strategy based on energy efficiency and renewable energy. A report commissioned by the Scottish Greens lays out the transition to a low-carbon economy by 2035, promising an overall gain in employment in sectors such as renewable energy, forestry, and building retrofitting [49]. Employees at INEOS' Grangemouth site - who would be adversely affected by this economic shift - are promised 15 years of job security thanks to shale gas deliveries from the US, followed by a "just transition for workers" [28].

\section{Explaining the Evolution of the Debate}

One way to explain the evolution of the debate over UGD (and associated policy-making) is to assess the relative discursive power of pro- and anti-UGD discourse coalitions, as Bomberg [7] has done for the UK. In Scotland, the different storylines cover an expansive discursive terrain and opinion polls indicate that anti-UGD narratives currently appear to outperform pro-UGD storylines. Table 2 suggests some resonant linkages, but this assessment remains tentative. Instead, the focus in this final section lies on explaining discursive shifts which have already taken place, specifically in relation to the pivotal role played by the Scottish government. Torn between growing public scepticism and potential economic opportunities, the Scottish government has long avoided taking a clear position. Its dual discursive strategy has further complicated matters.

The Scottish government can, in effect, be conceptualised as a separate, third discourse coalition whose 'evidence-based approach' to UGD has achieved discourse structuration and a considerable degree of discursive dominance. There are other undecided actors in this grouping which have not yet taken a firm position on UGD, such as the National Farmers' Union Scotland and the Church of Scotland. But it is appropriate to focus on the Scottish government as the undisputed discursive leader.

\section{The Evidence-Based Approach}

For the governing SNP, an extensive regulatory pause for gathering evidence has delivered strategic benefits. It has minimised electoral risk by ensuring that no decision would be taken before the UK General Election (May 2015) and the Scottish Parliament Election (May 2016) (Interviews H, I). This astute political manoeuvre has been underpinned by a discursive appeal to the government's competency and to the wisdom of proceeding on the basis of robust scientific evidence. Competent governance is affirmed by invoking a 'responsible', 'moderate', 'careful', and 'considered' approach. This is contrasted with strong pro- or anti-UGD stances taken by other political parties. Energy 
Minister Ewing declared that "[u]nlike the Conservatives [...] and the Labour Party, we take a sensible approach: we look for the evidence". He then demanded: "What could conceivably be wrong with that approach?" ([59]: 3).

Stakeholder and public consultations are an integral part of the government's approach. They are in line with its general tendency to make policy "through consultation, to gather evidence, seek consensus when it is there, and (when possible or appropriate) 'co-produce' policy with a wide range of people and organisations" [10]. Given the divisiveness of the UGD debate, genuine co-production may prove impossible. But the government has stressed that the moratorium has been welcomed by both industry and environmental NGOs (Scotsman, 10 March 2015). In addition to broad-based acceptance, the discursive dominance of the evidence-based approach has partly been achieved by sheer overwhelming repetition. As The Herald (4 March 2016) observes, any challenge to the government's policy on UGD is immediately parried by "trotting out" its "mantra" on evidence-based policy-making. Among the media sources analysed for this research, references to the evidencebased approach are almost always present.

Moreover, the flexible nature of this storyline should be noted. First articulated in February 2014 to legitimise a more cautious planning policy, by January 2015 it had become the overarching rationale for a moratorium. While pro-UGD actors often refer to a 'science-based approach' (Herald, 15 October 2015) and point to a supportive report by an expert scientific panel [57], anti-UGD actors employ the evidence-based approach to demand stringent precaution and, thus, a permanent ban (Interviews A, F, H). The government insists on a programme of evidence gathering, but also seeks to preserve its political leeway. Energy minister Ewing has called for a national debate informed by evidence, rational analysis, and a better understanding of public opinion [2]. This signifies an incipient shift towards a more flexible interpretation of the evidence-based approach and corresponds to an increasingly critical mood in the governing SNP. Barely a year after announcing the moratorium, the party's manifesto for the 2016 Scottish parliament elections went so far as to declare "deep scepticism" about UGD and vowed to block it unless it can be proven "beyond any doubt that there is no risk to health, communities or the environment" ([63]: 31). The main reason for the gradual drift from balanced evidence-based language towards a discourse of precaution is the strong resonance of a second, anti-Westminster storyline.

\section{The Fulcrum of Scottish Nationalism}

Scotland's political scene in 2013 and 2014 was dominated by the independence referendum. Yet, in making the economic case for independence, the SNP's campaign emphasised renewable energy and the offshore oil industry, while largely ignoring the potential of UGD (Scotsman, 10 October 2013). Just one month before the referendum, and responding to the UK government's plans to allow drilling under private land (below $300 \mathrm{~m}$ ) without consent, the SNP began to emphasise the distinctiveness of the Scottish government's position. Energy minister Ewing linked the issue to the emotive topic of land ownership and contrasted Scotland's "evidence-based, cautious and considered approach" with the UK government's "gung-ho approach". Instead, he argued, decisions on UGD should be taken by the people of Scotland. A 'yes' vote in the referendum would make this possible (Herald, 16 August 2014). This position became an integral part of the SNP's discourse after the referendum. A further transfer of UGD-related powers was agreed by the Smith Commission (2014), albeit not including UGD-related tax revenues. The UK's approach was regularly criticised, and the Scottish government unsuccessfully tried to justify its inaction on UCG (until October 2015) with relevant powers remaining with the UK government and the Coal Authority [3].

Once unleashed, the anti-Westminster and pro-independence storyline could not be politically contained in the way intended by the Scottish government. During the two election campaigns of 2015 and 2016, SNP supporters wore specially designed badges showing the party logo and the 
slogan 'Frack Off'. According to the SNP leadership, this signified that "fracking is off the agenda in Scotland" (Herald, 12 April 2016), but the slogan exactly mirrors the language used by anti-UGD campaigners. Pro-UGD actors responded with narratives of opportunity to frame UGD as a pathway to future independence, especially in a context of a declining oil price and flagging offshore operations. Tom Pickering of INEOS called UGD a "once-in-a-generation opportunity" (Herald, 14 October 2015), while the company's CEO Jim Ratcliffe hailed it as the "last chance to gain economic independence" [61]. He stoked the deep-running nationalist rivalry with England by warning that "[i]t would be a tragedy for Scotland if England ends up taking the lead in this exciting industry, and secures the jobs and investments" (Scottish Sun, 16 October 2015).

Despite their potential, these attempts of linking UGD with Scottish independence have not yet had a significant impact on public opinion or the SNP's position. The SNP did not merely have to contend with a surging Green party, but more importantly faced considerable internal divisions. With many SNP candidates campaigning locally against UGD, the issue was said to have even "more traction" among the party membership than the quest for a second independence referendum (Sunday Herald, 4 October 2015). The SNP leadership only narrowly avoided a motion on banning UGD at the 2015 Autumn party conference by toning it down significantly. Despite multiple motions, the topic was entirely excluded from the subsequent Spring conference (Scotsman, 23 January 2016). An internal anti-UGD group (SMAUG) was set up in September 2015 to mobilise and channel political pressure. The context for this has been auspicious, as SNP voters emerge as by far the most sceptical about UGD among the three main parties, with almost three quarters of them against prioritising the new technology [77].

Torrance [69] concludes that "a deep aversion to fracking has entered the soul of the party." At the 2015 Autumn party conference, SMAUG member lain Black transformed the party's battle cry about 'Scotland's oil' into a plea for protecting communities from adverse impacts: "now it's Scotland's land, it's Scotland's air, it's Scotland's water" (ibid.). UGD could have (and might still) become part of a revamped economic case for independence, but in the minds of many it has been "cast as 'Unionist' and therefore bad" (The Herald, 18 April 2016). To a significant extent, the combined impact of the anti-Westminster storyline and the five anti-UGD storylines has served to construct the technology as risky and undesirable, thus motivating an increasingly sceptical stance by the Scottish government.

\section{Conclusion}

This article has applied key concepts of ADA to unconventional gas in Scotland. Given the paucity of case-specific secondary academic literature, I have provided a detailed analysis of the main storylines used by pro- and anti-UGD discourse coalitions. ADA emphasises the dynamic nature of policy debates through which ideas, values, trust, and credibility can help to challenge and redefine a given set of interests. Carefully constructed storylines can be key tools of persuasion and begin to shift the balance both in the public debate and potentially in the policy process.

Both anti- and pro-UGD storylines have gained significant potency over the last few years. Some storylines primarily appeal to citizens' economic interests, but others are highly attuned to matters of trust and justice or seek to boost experiential commensurability and cultural resonance. Economyrelated storylines are overrepresented in the pro-UGD camp, while anti-UGD storylines cover a broader spectrum of resonant discourses.

The article's second main contribution is an interpretive assessment of discursive and political dynamics thus far. While anti-UGD actors have sought to politicise the issue of UGD since 2011, its level of political salience was significantly boosted by the Scottish government's (and the SNP's) decision to appropriate it for the Scottish independence campaign in 2014. The Scottish government 
is the evident linchpin in these developments - not merely due to this decision but also because it has managed to both structure the debate and temporarily institutionalise its preferred policy, namely the moratorium on all forms of UGD. Of particular importance is the discursive dominance of the government's 'evidence-based approach'. Embodied by the moratorium and invoking the authority of scientific knowledge, this strategy has attracted qualified support from the other discourse coalitions. But it has fallen short of discursive hegemony due to its avowedly temporary nature and the contradictory effects of the government's discursive strategy.

In principle, the government has retained considerable political leeway by acting as the gatekeeper with respect to what counts as sound evidence, what constitutes (un)acceptable risk, and how to organise the planned public consultation. But once the symbolic and discursive power of the antiWestminster storyline had been unleashed, it became difficult to contain. Political contestation continued to grow and the government's position was undermined by grassroots mobilisation in the SNP itself. Originally intended to work in combination with the anti-Westminster storyline, the evidence-based approach/storyline has at times been overshadowed by it. Overall, one can thus observe a discursive 'drift' from the construction of UGD as a relatively low-key issue (covered by a modestly reformed planning system) to increasing politicisation (prompting the moratorium) and, ultimately, the emergence of a precautionary narrative.

Similar dynamics of delay, evidence gathering, and eventual precautionary decisions can be observed in the Netherlands and New York State $[46,51,47]$ - which have instituted medium-term or indefinite moratoria - and they might serve as scenarios for predicting Scotland's regulatory trajectory. In turn, the Scottish experience may also hold lessons for UGD controversies in other countries. Besides the credibility and appeal of economic storylines in favour of UGD, non-economic or composite storylines may turn out to be crucial for the discursive (and political) power of anti-UGD groups. The existence of plausible alternative energy visions (particularly renewables) as well as the framing of industrial history (related to fossil fuel extraction) and its legacy may constitute key explanatory variables. Furthermore, discursive linkages with resonant governance- or identity-related debates - for instance, over Scottish independence or land reform - can provide considerable and lasting political salience. These factors deserve further analysis in the emerging comparative literature on UGD.

In the Scottish case, a strengthening of pro-UGD storylines and future shifts in public opinion remain a possibility and might be caused by exogenous factors, such as rapidly rising energy prices, economic downturns, or technological innovations that offer enhanced safety, lower costs, or climate mitigation benefits (e.g. propane-based fracking or carbon capture and storage). The UK Government's decision to phase out feed-in tariffs for onshore wind farms by April 2016 and its promise to set up a shale wealth fund (including payments to individual local householders) have also shifted incentives in favour of UGD. The UK's referendum on leaving the European Union (June 2016) and the possible prospect of a second Scottish independence referendum may equally affect public opinion and policy-making in yet unforeseen ways. Currently, however, the Scottish government's precautionary discourse and the Scottish Parliament's recent non-binding vote for a complete ban on UGD (Scotsman, 5 June 2016) indicate that the evidence-based approach could eventually result in an extended or indefinite moratorium. Whichever decision transpires, the long-term future of UGD in Scotland will undoubtedly be shaped by discursive battles fought with compelling and resonant storylines.

\section{Bibliography}


[1] Ashmoore, Olivia, Darrick Evensen, Chris Clarke, Jennifer Krakower and Jeremy Simon (2016). "Regional newspaper coverage of shale gas development across Ohio, New York, and Pennsylvania: Similarities, differences, and lessons". Energy Research \& Social Science, 11, pp. 119-132.

[2] BBC News (2015a). "Call for national debate on fracking in Scotland". 29 April. Available at http://www.bbc.co.uk/news/uk-scotland-32479225 (accessed 31/05/2016).

[3] BBC News (2015b). "Fracking moratorium 'should be extended' to underground coal gasification'". 22 February. Available at http://www.bbc.co.uk/news/uk-scotland-31554251 (accessed 07/06/2016).

[4] Benford, Robert D. and David A. Snow (2000). "Framing Processes and Social Movements: An Overview and Assessment". Annual Review of Sociology, 26, pp. 611-639.

[5] Biggar Economics (2015). Underground Coal Gasification: Economic Impact Assessment. Roslin, Midlothian. Available at http://www.cluffnaturalresources.com/wpcontent/uploads/2016/01/3-Economic-Impact-Assessment-21-September-2015.pdf (accessed 07/06/2016).

[6] Blair, Benjamin D., Christopher M. Weible, Tanya Heikkila and Larkin McCormack (2015). "Certainty and Uncertainty in Framing the Risks and Benefits of Hydraulic Fracturing in the Colorado News Media". Risk, Hazards \& Crisis in Public Policy, 6(3), pp. 290-307.

[7] Bomberg, Elizabeth (2015). "Shale We Drill? Discourse Dynamics in UK Fracking Debates". Journal of Environmental Policy \& Planning, published online 10/06/2015.

[8] Bryman, Alan (2012). Social Research Methods. 4th edition, Oxford: Oxford University Press.

[9] Bulkeley, Harriet (2000). "Discourse coalitions and the Australian climate change policy network". Environment and Planning C, 18(6), pp. 727-748.

[10] Cairney, Paul (2015). "The fracking moratorium in Scotland: what is it for? To gather new evidence?". 28 January. Available at https://paulcairney.wordpress.com/2015/01/28/thefracking-moratorium-in-scotland-what-is-it-for-to-gather-new-evidence/ (accessed 07/06/2016).

[11] Cairney, Paul, Manuel Fischer and Karin Ingold (2016). "Hydraulic Fracturing Policy in the United Kingdom: Coalition, Cooperation and Opposition in the Face of Uncertainty". In: C. M. Weible, T. Heikkila, K. Ingold and M. Fischer (eds.). Policy Debates on Hydraulic Fracturing: Comparing Coalition Politics in North America and Europe. London: Palgrave.

[12] Church of Scotland (2015). Report of the Church and Society Council. Available at http://www.churchofscotland.org.uk/_data/assets/pdf_file/0017/27125/Church_and_Socie ty_Council.pdf (accessed 08/08/2016).

[13] CNR (2015a). Cluff Natural Resources - Firth of Forth UCG Project. Available at https://www.documentcloud.org/documents/2180516-unredacted-cluff-ucg-briefing.html (accessed 07/06/2016).

[14] CNR (2015b). Letter to Fergus Ewing MSP, Minister of Energy. 24 March. Available at https://www.documentcloud.org/documents/2182964-cluff-letter-to-ewing.html (accessed 07/06/2016).

[15] Cotton, Matthew (2015). "Stakeholder Perspectives on Shale Gas Fracking: A Q-method Study of Environmental Discourses". Environment and Planning A, 47(9), pp. 1944-1962.

[16] Cotton, Matthew (2016). "Fair fracking? Ethics and environmental justice in United Kingdom shale gas policy and planning". Local Environment, published online before print 27 May.

[17] Cotton, Matthew, Imogen Rattle and James Van Alstine (2014). "Shale gas policy in the United Kingdom: An argumentative discourse analysis". Energy Policy, 73, pp. 427-438.

[18] Davidson, Debra J. and Mike Gismondi (2011). Challenging Legitimacy at the Precipice of Energy Calamity. New York: Springer.

[19] Dodge, Jennifer and Jeongyoon Lee (2015). "Framing Dynamics and Political Gridlock: The Curious Case of Hydraulic Fracturing in New York". Journal of Environmental Policy \& Planning, published online 07/12/2015.

[20] Dryzek, John S. (2005). The Politics of the Earth: Environmental Discourses. 2nd edition, Oxford: Oxford University Press. 
[21] Evensen, Darrick (2015). "Policy Decisions on Shale Gas Development ('Fracking'): The Insufficiency of Science and Necessity of Moral Thought". Environmental Values, 24(4), pp. 511-534.

[22] Evensen, Darrick (2016). "Ethics and 'Fracking': A Review of (the Limited) Moral Thought on Shale Gas Development". Wiley Interdisciplinary Reviews: Water, 3(4), pp. 575-586.

[23] Farquharson, Kenny (2015). "SNP must end the moratorium on fracking". The Times, 19 June.

[24] FAUG (2014). "Community Charter". Available at http://faug.org.uk/community_charter.pdf (accessed 07/06/2016).

[25] FAUG (2015). Briefing Sheet - INEOS Plans to Frack Scotland. Event leaflet (on record with author).

[26] Fischer, Frank (2003). Reframing Public Policy: Discursive Politics and Deliberative Practices. Oxford: Oxford University Press.

[27] FOE (2015). No need to step on the gas. Available at https://www.foe.co.uk/sites/default/files/downloads/no-need-step-gas-76983.pdf (accessed 07/06/2016).

[28] FOES (2015a). Dirty frackers, dodgy numbers. Available at http://www.foescotland.org.uk/sites/www.foescotland.org.uk/files/Dirty\%20Frackers,\%20Dodgy\%20Numbers,\%20Sept\%202015.pdf (accessed 07/06/2016).

[29] FOES (2015b). "Scottish Labour pledge to halt fracking". 24 January. Available at http://www.foe-scotland.org.uk/Scottish-Labour-fracking (accessed 07/06/2016).

[30] FOES (2015c). Unconventional Gas \& Fracking Myth Buster. Available at http://www.foescotland.org.uk/sites/www.foescotland.org.uk/files/Unconventional\%20Gas\%20\&\%20Fracking\%20Myth\%20Buster,\%20Mar ch\%202015.pdf (accessed 07/06/2016).

[31] FOES (2015d). Unconventional Gas: unsafe, unnecessary, unwanted. Available at http://www.foe-scotland.org.uk/sites/www.foescotland.org.uk/files/Unconventional\%20Gas\%20unsafe,\%20unwanted,\%20unecessary\%20Jan\%202015.pdf (accessed 07/06/2016).

[32] GMB Scotland (2015). "Fracking Debate Needed In Scotland". 9 November. Available at http://www.gmb.org.uk/newsroom/fracking-debate-needed-in-scotland (accessed 07/06/2016).

[33] Goldthau, Andreas and Benjamin K. Sovacool (forthcoming). "Energy Technology, Politics, and Interpretative Frames: The Case of Shale Gas Fracking in Eastern Europe". Global Environmental Politics.

[34] Hajer, Maarten (1995). The Politics of Environmental Discourse: Ecological Modernization and the Policy Process. Oxford: Clarendon Press.

[35] Hajer, Maarten (2006). "Doing discourse analysis: coalitions, practices, meaning". In: M. van den Brink and T. Metze (eds.). Words Matter in Policy and Planning: Discourse Theory and Method in the Social Sciences. Utrecht: Netherlands Graduate School of Urban and Regional Research.

[36] Hajer, Maarten (2009). Authoritative Governance: Policy Making in the Age of Mediatization. Oxford: Oxford University Press.

[37] Hawkins, Joanne (2015). "Fracking: Minding the gaps". Environmental Law Review, 17(1), pp. 821.

[38] Hays, Jake, Madelon L. Finkel, Michael Depledge, Adam Law and Seth B. C. Shonkoff (2015). "Considerations for the development of shale gas in the United Kingdom". Science of the Total Environment, 512, pp. 36-42.

[39] Hilson, Chris (2015). "Framing Fracking: Which Frames Are Heard in English Planning and Environmental Policy and Practice?". Journal of Environmental Law, 27(2), pp. 177-202.

[40] INEOS (2015a). The Reasons for Extracting Shale Gas. Grangemouth: Ineos Upstream. Available at 
http://www.ineos.com/Global/Upstream/Films\%20Literature/Reasons\%20for\%20ExtractingV4.pdf (accessed 07/06/2016).

[41] INEOS (2015b). Shale Gas: Your Questions Answered. Grangemouth: INEOS Upstream. Available at http://www.ineos.com/Global/Upstream/Films\%20Literature/Q-and-Av3.pdf (accessed 07/06/2016).

[42] INEOS (2015c). "Why Shale Gas?". Available at http://www.ineos.com/businesses/ineosupstream/why-shale-gas/\#why-shale- (accessed 07/06/2016).

[43] Jaspal, Rusi and Brigitte Nerlich (2014). "Fracking in the UK Press: Threat Dynamics in an Unfolding Debate". Public Understanding of Science, 23(3), pp. 348-363.

[44] Jenkins, Kirsten, Darren McCauley, Raphael Heffron, Hannes Stephan and Robert Rehner (2016). "Energy Justice: A Conceptual Review". Energy Research \& Social Science, 11, pp. 174-182.

[45] Lander, Ric (2013). "After 160 years Central Scotland has had enough". 11 June. Available at https://riclander.wordpress.com/2013/07/21/after-160-years-central-scotland-has-hadenough/ (accessed 26/08/2016).

[46] Metze, Tamara (2014). "Fracking the Debate: Frame Shifts and Boundary Work in Dutch Decision Making on Shale Gas". Journal of Environmental Policy \& Planning, published online 11/08/2014.

[47] Metze, Tamara and Jennifer Dodge (2016). "Dynamic Discourse Coalitions on Hydro-fracking in Europe and the United States". Environmental Communication, 10(3), pp. 365-379.

[48] Miller, William L. and Benjamin F. Crabtree (1999). "Using Codes and Code Manuals: A Template Organizing Style of Interpretation". In: B. F. Crabtree and W. L. Miller (eds.). Doing Qualitative Research. 2nd edition, London: Sage, pp. 163-177.

[49] Minio-Paluello, Mika (2015). Jobs in Scotland's New Economy. Report commissioned by the Scottish Green MSPs. Available at https://www.scottishgreens.org.uk/wpcontent/uploads/downloads/2015/08/Jobs_in_Scotland_New_Economy.pdf (accessed 07/06/2016).

[50] Monaghan, A. A. (2014). The Carboniferous shales of the Midland Valley of Scotland: geology and resource estimation. London: British Geological Survey.

[51] Northrup, Chip (2014). "A Brief History of the New York State Frack Ban Movement". 21 December. Available at http://www.nofrackingway.us/2014/12/21/a-brief-history-of-thenew-york-frack-ban-movement/ (accessed 20/08/2016).

[52] Ockwell, David G. and Yvonne Rydin (2010). "Analysing dominant policy perspectives: the role of discourse analysis". In: J. C. Lovett and D. G. Ockwell (eds.). A Handbook of Environmental Management. Cheltenham: Edward Elgar, pp. 168-197.

[53] Palmer, James (2010). "Stopping the unstoppable? A discursive-institutionalist analysis of renewable transport fuel policy". Environment and Planning C, 28(6), pp. 992-1010.

[54] Scottish Energy News (2015a). "Cluff confirms Kincardine coal-gas plan remains 'a flagship' energy project.". 28 August. Available at http://www.scottishenergynews.com/cluffconfirms-kincardine-coal-gas-plan-remains-a-flagship-energy-project/ (accessed 07/06/2016).

[55] Scottish Energy News (2015b). "Forthcoming low-carbon Forth Estuary coal-gasification development could dwarf Scottish renewables wind energy". 24 February. Available at http://www.scottishenergynews.com/forthcoming-low-carbon-forth-estuary-coalgasification-development-could-dwarf-scottish-renewables-wind-energy/ (accessed 07/06/2016).

[56] Scottish Environment Link (2014). Scotland and the Carbon Bubble. Available at http://www.scotlink.org/wp/files/documents/Scotland-and-the-carbon-bubble-final-forpublication.pdf (accessed 07/06/2016).

[57] Scottish Government (2014). Independent Expert Scientific Panel - Report on Unconventional Oil And Gas. Edinburgh. Available at http://www.gov.scot/Resource/0045/00456579.pdf (accessed 07/06/2016).

[58] Scottish Parliament (2014). Official Report - Meeting of the Parliament. 7 May 2014.

[59] Scottish Parliament (2016). Official Report - Meeting of the Parliament. 17 March 2016. 
[60] Scrase, Ivan J. and David G. Ockwell (2011). "The role of discourse and linguistic framing in sustaining high carbon energy policy - An accessible introduction". Energy Policy, 38(5), pp. 2225-2233.

[61] Shale Gas International (2015b). "Scotland rejects outright ban on fracking". 21 October. Available at http://www.shalegas.international/2015/10/21/scotland-rejects-outright-banon-fracking/ (accessed 07/06/2016).

[62] Smith Commission (2014). Report of the Smith Commission for further devolution of powers to the Scottish Parliament. 27 November. Available at https://www.smith-commission.scot/wpcontent/uploads/2014/11/The_Smith_Commission_Report-1.pdf (accessed 07/06/2016).

[63] SNP (2016). SNP Manifesto 2016. Available at https://d3n8a8pro7vhmx.cloudfront.net/thesnp/pages/5409/attachments/original/1461145 824/SNP_Manifesto2016-web.pdf?1461145824 (accessed 20/05/2016).

[64] Sovacool, Benjamin K. and Ishani Mukherjee (2011). "Conceptualizing and Measuring Energy Security: A Synthesized Approach". Energy, 36(8), pp. 5343-5355.

[65] Survation (2016). "April Scottish Attitudes Poll". Available at http://survation.com/wpcontent/uploads/2016/04/Scomnibus-IV-15661626471-140416DCCH-1c0d0h5.pdf (accessed 07/06/2016).

[66] Syracuse.com (2014). "New York's hydrofracking ban: a political decision draped in science". 28 December. Available at http://www.syracuse.com/opinion/index.ssf/2014/12/new_yorks_hydrofracking_ban_drape s_a_political_decision_in_science_editorial.html (accessed 20/08/2016).

[67] The Royal Society and Royal Academy of Engineering (2012). Shale gas extraction in the UK: a review of hydraulic fracturing. Available at http://www.raeng.org.uk/publications/reports/shale-gas-extraction-in-the-uk (accessed 07/06/2016).

[68] Torfing, Jacob (2011). "Policy, Discourse Models". In: B. Badie (ed.), International Encyclopedia of Political Science. London: Sage, pp. 1881-1884.

[69] Torrance, David (2015). "SNP is caught between rock and a hard place on fracking". The Herald, 19 October.

[70] UKOOG (2013). Fact Sheet: The History of Onshore Oil and Gas. Available at http://www.ukoog.org.uk/images/ukoog/pdfs/fact\%20sheets/history.pdf (accessed 07/06/2016).

[71] UKOOG (2014). Getting ready for UK shale gas: Supply chain and skills requirements and opportunities. London: EY and Ernst \& Young. Available at http://www.ukoog.org.uk/images/ukoog/pdfs/Getting_ready_for_UK_shale2_gas_FINAL202 2.04.14.pdf (accessed 07/06/2016).

[72] Upham, Paul, Aleksandra Lis, Hauke Riesch and Piotr Stankiewicz (2015). "Addressing social representations in socio-technical transitions with the case of shale gas". Environmental Innovation and Societal Transitions, 16, pp. 120-141.

[73] Weingart, Peter (1999). "Scientific Expertise and Political Accountability: Paradoxes of Science in Politics". Science and Public Policy, 26(3), pp. 151-161.

[74] Williams, Laurence, Phil Macnaghten, Richard Davies and Sarah Curtis (2015). "Framing 'Fracking': Exploring Public Perceptions of Hydraulic Fracturing in the United Kingdom". Public Understanding of Science, published online before print 13 July.

[75] WWF Scotland (2014). Scotland: A Renewable Powerhouse. Dunkeld: Blackwood Environmental Consulting. Available at http://assets.wwf.org.uk/downloads/powerhouse_1.pdf (accessed 07/06/2016).

[76] YouGov (2015). "YouGov / The Times Survey Results". 09-13/10/2015. Available at https://d25d2506sfb94s.cloudfront.net/cumulus_uploads/document/mr8k4ikbr3/TimesResu Its_October15_ScotlandVI,tax,parties_w.pdf (accessed 07/06/2016).

[77] YouGov (2016). "YouGov / Scottish Renewables Survey Results". 15/02/2016. Available at https://d25d2506sfb94s.cloudfront.net/cumulus_uploads/document/yvtrw0ymeh/Scottish_ Renewable_Results_160222_Website.pdf (accessed 07/06/2016). 
[78] Young, Ellen (2015a). "The Anti-Fracking Movement and the Struggle for Land Sovereignty". In: The Post Collective \& Scottish Land Action Movement (eds.), Our Land, Our Future.

Edinburgh: The Post Collective, pp. 14-17.

[79] Young, Ellen (2015b). "A Community Response to Unconventional Gas - Interview with Jamie Hamilton (Concerned Communities of Falkirk)". In: The Post Collective (ed.), Potential Energy: The Politics of Energy in Scotland. Edinburgh: The Post Collective, pp. 26-34. 